\title{
ANALISIS KANDUNGAN LOGAM BERAT TIMBAL Pb PADA KERANG Polymesoda erosa $L$ DI PERAIRAN TANJUNG BUNGA MAKASSAR
}

\author{
Eka Apriyanti ${ }^{1}$ \\ ${ }^{1}$ Universitas Pembangunan Indonesia, Makassar \\ email:eka.apriyanti@rocketmail.com
}

\begin{abstract}
This study aims to determine the heavy metal content of Lead $(\mathrm{Pb})$ on polymesoda erosa $\mathrm{L}$ shells taken in the waters of Tanjung Bunga Makassar. This is based on the habits of people who love to consume this water biota. Shellfish is a good source of protein for the body but on the other side of the shell is a living biota of sedil (sedentary) that can accumulate a number of contaminants found in waters such as heavy metals Pb. Shellfish is a biocatalisator of environmental pollution. The variables studied in this study are heavy metal content of lead $\mathrm{Pb}$ on shell Polymesoda erosa L. Sampling is done by purposive sampling in the waters of Tanjung Bunga Makassar. The shell of Polymesoda erosa L was taken as a dried-off study sample. Subsequently, the sample analyzed its $\mathrm{Pb}$ content with ESI (Selectif Ion Electrode) in Chemical Analytical Laboratory of Chemistry Department of FMIPA UNHAS. The results showed that the Pb content of Polymesoda erosa L shells was 1.07 $\mathrm{mg} / \mathrm{kg}-2.05 \mathrm{mg} / \mathrm{kg}$. Based on the Decree of the Directorate General of POM RI, the limit of heavy metal content of lead $(\mathrm{Pb})$ in the permitted quality standard for fish products (other seafood) is $2 \mathrm{mg} / \mathrm{kg}$. This indicates that the lead content of $\mathrm{Pb}$ in the shell of Polymesoda erosa $\mathrm{L}$ in the Tanjung Bunga Waters of Makassar has exceeded the predetermined threshold so it is declared unfit for consumption by the public. This study recommends to the public to be careful in consuming shellfish and to the City Government to anticipate more complex environmental pollution, especially in the waters of Tanjung Bunga Makassar.
\end{abstract}

Keywords: Pollutant, Heavy Metal, Water Biota, Shellfish, Pollution, Lead (Pb), ESI.

\begin{abstract}
Abstrak
Penelitian ini bertujuan mengetahui kandungan logam berat Timbal $(\mathrm{Pb})$ pada kerang Polymesoda erosa $L$ yang diambil di perairan Tanjung Bunga Makassar. Hal ini didasarkan pada kebiasaan masyarakat yang senang mengkonsumsi biota air ini. Kerang merupakan sumber protein yang baik untuk tubuh namun di sisi lain kerang merupakan biota air yang hidupnya sesil (menetap) yang dapat mengakumulasi sejumlah bahan pencemar yang terdapat di perairan seperti logam berat $\mathrm{Pb}$. Kerang merupakan biokatalisator pencemaran lingkungan.Variabel yang dikaji dalam penelitian ini adalah kandungan logam berat timbal $\mathrm{Pb}$ pada kerang Polymesoda erosa $\mathrm{L}$. Pengambilan sampel dilakukan secara purposive sampling di perairan Tanjung Bunga Makassar. Tubuh kerang Polymesoda erosa $L$ yang diambil sebagai sampel penelitian didestruksi kering. Selanjutnya sampel dianalisis kandungan $\mathrm{Pb}$ nya dengan ESI (Elektroda Selectif Ion) di laboratorium Kimia Analitik Jurusan Kimia FMIPA UNHAS. Hasil analisis menunjukkan adanya kandungan $\mathrm{Pb}$ pada kerang Polymesoda erosa $L$ antara $1,07 \mathrm{mg} / \mathrm{kg}$ $-2,05 \mathrm{mg} / \mathrm{kg}$. Berdasarkan Surat Keputusan Direktorat Jenderal POM RI batas kandungan logam berat timbal $(\mathrm{Pb})$ dalam baku mutu yang diizinkan untuk produk ikan (hasil laut lainnya) adalah $2 \mathrm{mg} / \mathrm{kg}$. Ini menunjukkan bahwa kandungan timbal $\mathrm{Pb}$ pada kerang Polymesoda erosa L di Perairan Tanjung Bunga Makassar telah melampaui ambang batas yang telah ditetapkan sehingga dinyatakan tidak layak dikonsumsi oleh masyarakat. Studi ini merekomendasikan kepada masyarakat untuk berhati-hati dalam mengkonsumsi kerang dan kepada Pemerintah Kota agar mengantisipasi pencemaran lingkungan yang lebih kompleks khususnya di perairan Tanjung Bunga Makassar.
\end{abstract}

Kata kunci: Polutan, Logam berat, Biota air, Kerang, Pencemaran, Timbal (Pb), ESI. 


\section{PENDAHULUAN}

Pada saat ini pencemaran berlangsung di mana-mana dengan laju yang begitu cepat, yang tidak pernah terjadi sebelumnya. Kecenderungan pencemaran akhir-akhir ini mengarah kepada dua hal yakni pembuangan senyawa-senyawa kimia tertentu yang terus meningkat, dan penggunaan bahan berbahaya beracun $\left(B_{3}\right)$ oleh berbagai kegiatan industri dengan pembuangan limbahnya ke lingkungan. Sewaktu manusia jumlahnya masih sangat sedikit, maka alam masih mampu membersihkan dirinya sendiri dari segala macam buangan atau kotoran dengan mekanisme yang berada di alam (ekosistem), yang dikenal sebagai self purification process melalui siklus hidrobiogeokimianya.

Seiring dengan pesatnya perkembangan teknologi serta meningkatnya aktivitas manusia yang semakin kompleks, konsentrasi pencemar dalam air sudah semakin tinggi dengan masuknya limbah rumah tangga dan asap kendaraan bermotor serta bahan kimia yang kadang kala sangat berbahaya dan beracun serta berpotensi menimbulkan efek negatif bagi perairan dan komponen biotik yang ada didalamnya.

Sebagai suatu wilayah geografis, Makassar merupakan salah satu pusat pemerintahan, jasa, pendidikan, niaga, industrialisasi dan berbagai kegiatan pembangunan, serta memiliki jumlah penduduk sekitar 1,2 juta jiwa, dengan luas wilayah sekitar $17,7 \mathrm{~km}^{2}$ memiliki tingkat mobilitas dan rutinitas kerja penduduk yang tinggi. Sungai dan Laut seringkali menjadi muara akhir dari pembuangan limbah. Bila ditinjau dari sekian ribu rumah tangga, industri, kegiatan pembangunan, transportasi, setiap harinya berpotensi menghasilkan limbah yang di dalamnya diprediksi terdapat zat-zat berbahaya berupa logam berat. Limbah-limbah tersebut akan terbuang melalui saluran-saluran pembuangan yang terdapat di dalam kota dan selanjutnya mengarah ke perairan Tanjung Bunga, dan secara tidak langsung perairan Tanjung Bunga akan tercemar. 
Kerang laut merupakan kelompok molluska yang hidup di daerah perairan laut dangkal dan juga ditemukan pada laut dalam. Kerang laut di kawasan pesisir sebagai penyusun komunitas makrozoobentos yaitu organisme yang menempati substrat dasar perairan, baik di atas maupun di dalam sedimen dasar perairan. Kerang tersebut memiliki keanekaragaman yang tinggi dibanding kerang yang hidup di perairan tawar.

Apabila manusia mengkonsumsi kerang yang mengandung logam berat dalam jumlah yang cukup tinggi akan berdampak negatif terhadap kesehatan. Beberapa logam berat yang umum ditemukan dalam kerang adalah timbal $(\mathrm{Pb})$, kadmium $(\mathrm{Cd})$, tembaga $(\mathrm{Cu})$, dan seng (Zn). Dalam tubuh manusia, logam berat akan bersenyawa dengan enzim aktif menjadi enzim tidak aktif, sehingga sintesis butir darah merah $(\mathrm{Hb})$ dapat dihambat, akibatnya dapat menimbulkan penyakit anemia (Sorensen, 1991).

Beberapa zat beracun yang telah mencemari perairan pantai sebagai akibat aktivitas antropogenik salah satunya adalah dari logam berat. Kerang merupakan biota yang potensial terkontaminasi logam berat, karena hidupnya di dalam sedimen (lumpur) sehingga biota ini sering digunakan sebagai hewan uji dalam pemantauan tingkat akumulasi logam berat pada organisme laut.

Berdasarkan uraian di atas, maka dianggap perlu untuk menganalisis kandungan logam berat $\mathrm{Pb}$ di Perairan Tanjung Bunga Makassar.

\section{METODOLOGI}

Lokasi penelitian berada dalam wilayah administrasi Kota Makassar yakni di Perairan Tanjung Bunga Makassar. Pengambilan sampel kerang dilakukan dengan cara purpossive sampling atau adjustmental sampling yaitu kerang diperoleh dari setiap sub plot yang telah dibuat. 
a. Tahap Pengambilan Sampel

Sampel diambil dari sub plot yang telah dibuat:

- Sub plot $A_{1}$ terletak di sebelah Utara sub plot $A_{2}$ dan di sebelah Timur sub plot $A_{4}$ dengan jarak masing-masing $15 \mathrm{~m}$ dan $90 \mathrm{~m}$.

- Sub plot $A_{2}$ terletak di sebelah Selatan sub plot $A_{1}$ dan di sebelah Timur sub plot $A_{5}$ dengan jarak masing-masing $15 \mathrm{~m}$ dan $90 \mathrm{~m}$.

- Sub plot $A_{3}$ berada tepat di perpotongan diagonal pada plot pengambilan sampel.

- Sub plot $A_{4}$ terletak di sebelah Utara sub plot $A_{5}$ dan di sebelah Barat sub plot $A_{1}$ dengan jarak masing-masing $15 \mathrm{~m}$ dan $90 \mathrm{~m}$.

- Sub plot $A_{5}$ terletak di Sebelah Barat sub plot $A_{2}$ dan di sebelah Selatan sub plot $A_{4}$ dengan jarak masing-masing $15 \mathrm{~m}$ dan $90 \mathrm{~m}$.

Sampel dengan jumlah yang cukup harus diambil untuk memperoleh sampel yang mewakili/representatif (Michael, 1994). Jumlah sampel pada setiap sub plot sebanyak 25 kerang. Pengambilan sampel dilakukan pada saat air surut sekitar jam 06.00 Wita. Daerah pengambilan sampel antara 10-30 m dari bibir pantai dengan kedalaman 7-30 cm.

b. Tahap Pelaksanaan

1) Pembuatan Larutan Standar

$\mathrm{Pb}$ Nitrat atau $\mathrm{Pb}\left(\mathrm{NO}_{3}\right)_{2}$ dalam bentuk serbuk ditimbang 3,312 $\mathrm{g}$, untuk memperoleh larutan dengan konsentrasi 0,1 Molar dan volume 0,1 L. Larutan yang digunakan sebagai larutan standar yaitu memiliki konsentrasi $1 \times 10^{-9}$ Molar hingga $1 \times 10^{-1}$ Molar, dengan masing-masing volume $50 \mathrm{ml}$.

2) Preparasi Sampel:

Sampel dilepas dari cangkang setelah itu dibersihkan dengan aquadest. Sampel diletakkan di petri disk yang telah disterilisasi. Kemudian dimasukkan ke dalam oven dengan suhu $60^{\circ} \mathrm{C}$ selama 2 × 24 jam. Sampel yang telah kering dihaluskan dengan 
menggunakan blender kemudian digerus sampai halus. Sampel yang halus ditimbang sebanyak 2 g lalu dimasukkan ke dalam bom teflon serta ditambahkan $20 \mathrm{ml} \mathrm{HNO}_{3}$ p.a dan $2 \mathrm{ml} \mathrm{HClO}_{4}$ p.a. Bom Teflon yang berisi larutan dimasukkan kedalam oven dengan suhu $200^{\circ} \mathrm{C}$ selama 2 jam. Sampel dikeluarkan dari bom teflon lalu disaring dengan menggunakan kertas saring whatman no. 42 dan filtratnya ditampung ke dalam labu ukur $50 \mathrm{ml}$ serta dicukupkan volumenya hingga $50 \mathrm{ml}$ menggunakan aquadest. Larutan sampel siap diukur menggunakan $\mathrm{ESI} \mathrm{Pb}$ (II) atau ESI $\mathrm{Pb}^{2+}$.

Sampel yang telah diperoleh didestruksi kering kemudian proses analisis kandungan logam berat $\mathrm{Pb}$ dikerjakan di Laboratorium Analitik Jurusan Kimia FMIPA UNHAS dengan menggunakan alat ESI $\mathrm{Pb}^{2+}$ (Elektroda Selektif Ion).

Bagan Prosedur Kerja Analisis Timbal (Pb) menggunakan ESI Pb (II)

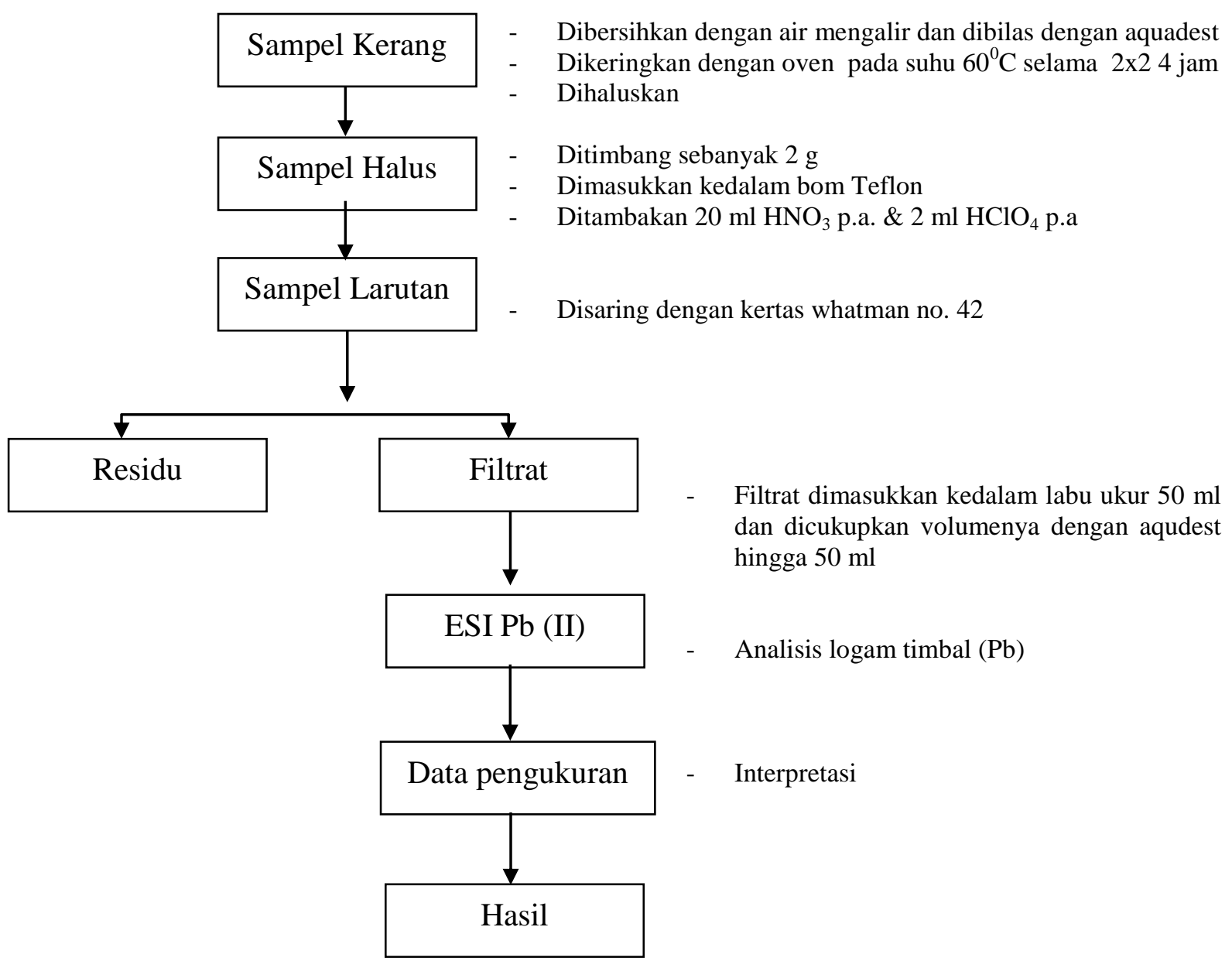

(Miller, 1982) 
Kadar logam berat timbal $\mathrm{Pb}$ dalam masing-masing sampel dinyatakan dengan ppm yang dihitung dengan menggunakan bantuan persamaan garis regresi. Untuk menentukan konsentrasi larutan sampel maka nilai absorbannya dapat dibuatkan dalam kurva standar. Untuk mendapatkan berat kering sampel maka nilai konsentrasi logam dalam larutan dikonversi ke dalam satuan $\mathrm{mg} / \mathrm{kg}$.

Rumus persamaan garis regresi untuk menentukan konsentrasi kerang dalam ppm: Keterangan:

$$
\begin{aligned}
& \mathrm{y}=\mathrm{ax}+\mathrm{b} \\
& \mathrm{y}=\text { Absorbansi } \\
& \mathrm{x}=\text { Konsentrasi } \\
& \mathrm{a}=\bar{\Sigma} \text { absorbansi } / \bar{\Sigma} \text { konsentrasi } \\
& \mathrm{b}=\bar{\Sigma} \text { sampel }
\end{aligned}
$$




\section{HASIL DAN PEMBAHASAN}

Hasil analisis laboratorium kandungan timbal $(\mathrm{Pb})$ pada kerang Polymesoda erosa L. dapat dilihat pada Tabel berikut:

Tabel 1. Kandungan logam berat timbal pada kerang Polymesoda erosa L. yang diperoleh di perairan Tanjung Bunga Makassar.

\begin{tabular}{|c|c|c|c|}
\hline \multirow{2}{*}{ Lokasi Sampel } & \multirow{2}{*}{ Potensial Pb (II) } & \multicolumn{2}{|c|}{ Konsentrasi } \\
\cline { 3 - 4 } & & $\mathrm{M}$ & $\mathrm{mg} / \mathrm{kg}$ \\
\hline $\mathrm{A}_{1}$ & 280,5 & $2,63 \times 10^{-7}$ & 1,33 \\
$\mathrm{~A}_{2}$ & 283,3 & $3,34 \times 10^{-7}$ & 1,62 \\
$\mathrm{~A}_{3}$ & 278,6 & $2,26 \times 10^{-7}$ & 1,15 \\
$\mathrm{~A}_{4}$ & 277,4 & $2,04 \times 10^{-7}$ & 1,07 \\
$\mathrm{~A}_{5}$ & 285,7 & $4,01 \times 10^{-7}$ & 2,05 \\
\hline
\end{tabular}

Setelah dilakukan pengukuran larutan standar $\mathrm{Pb}^{2+}$ maka dapat digambarkan grafik dari perhitungan persaamaan garis regresi sebagai berikut:

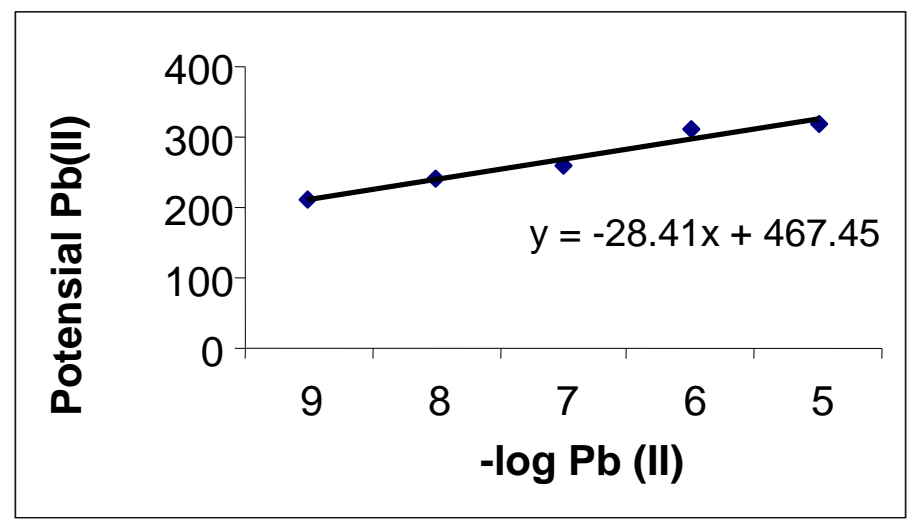

Gambar 3.1. Grafik persamaan garis regresi

Berdasarkan hasil analisis pada Tabel 3.1 terlihat bahwa dari semua sampel kerang Polymesoda erosa L yang diperoleh di perairan Tanjung Bunga Makassar dan telah diperiksa kandungan logam beratnya dalam hal ini timbal $(\mathrm{Pb})$, ternyata semua sampel terdeteksi mengakumulasi logam tersebut dengan kandungan sebesar antara 1,07 mg/kg hingga 2,05 $\mathrm{mg} / \mathrm{kg}$. 
Kualitas air laut pada perairan Tanjung Bunga Makassar pada pukul 06.00 Wita memiliki suhu antara $27-28^{\circ} \mathrm{C}$ serta $\mathrm{pH}$ antara 6-7. Kualitas air tersebut merupakan nilai dalam batas yang layak untuk mendukung aktivitas biota laut. Dengan demikian kualitas air pada lokasi penelitian diasumsikan memberikan pengaruh yang sama terhadap absorbsi timbal $(\mathrm{Pb})$ pada Polymesoda erosa $L$.

Kandungan logam berat timbal $(\mathrm{Pb})$ yang telah diperiksa pada kerang Polymesoda erosa $L$ memperlihatkan bahwa kandungan logam berat timbal $(\mathrm{Pb})$ berkisar antara 1,07 $\mathrm{mg} / \mathrm{kg}-2,05 \mathrm{mg} / \mathrm{kg}$. Jika dikaitkan dengan kandungan logam berat timbal $(\mathrm{Pb})$ yang direkomendasikan oleh Dirjen POM RI yaitu batas maksimum logam berat timbal $(\mathrm{Pb})$ untuk baku mutu ikan dan hasil olahannya adalah sebesar $2 \mathrm{mg} / \mathrm{kg}$, maka dapat dinyatakan bahwa kandungan logam berat timbal $(\mathrm{Pb})$ yang terakumulasi pada kerang Polymesoda erosa $L$ hasil analisisnya melewati batas yang telah ditetapkan, artinya kerang Polymesoda erosa L tidak layak dikonsumsi oleh masyarakat.

Kerang merupakan indikator pencemaran dalam perairan, ini dikarenakan sifat hidupnya yang sesil (menetap) dan cara pengambilan makanannya dengan hanya menyaring makanan (filter feeding) yang terlarut dalam air. Kerang hanya memperoleh makanan dari benda-benda yang terhanyut dalam air. Hal ini sangat memungkinkan untuk mengakumulasi pencemaran di air khususnya pencemaran logam berat timbal $(\mathrm{Pb})$. Selain makanannya hanya yang terhanyut dalam air ditunjang pula oleh proses pernafasannya yang menggunakan insang. Kerang memperoleh oksigen lewat air yang masuk ke dalam insang yang apabila mengandung logam berat berupa timbal $(\mathrm{Pb})$, maka secara otomatis logam berat timbal $(\mathrm{Pb})$ tersebut dapat terakumulasi di dalam tubuh kerang.

Logam berat timbal ( $\mathrm{Pb})$ masuk ke kerang Polymesoda erosa $L$ melalui dua cara. Yang pertama melalui organ respirasi yang dimiliki kerang berupa insang. Udara masuk melalui sifon ventral masuk ke insang lalu dikeluarkan melalui sifon dorsal. Yang kedua 
melalui saluran pencernaan, partikel makanan masuk melalui sifon ventral dengan sistem filter feeding, kemudian oleh gerakan silia yang terdapat pada palpus labialis, partikel makanan tersebut dimasukkan ke mulut yang terletak diantara sepasang palpus labialis, kemudian masuk ke oesofagus yang pendek. Dari oesofagus berlanjut ke lambung yang terletak di sebelah dorsal massa visceral, selanjutnya ke usus bagian dorsal kaki. Feces yang keluar dari anus akan dikeluarkan dari tubuh bersamaan dengan aliran air yang menuju ke sifon dorsal.

Kandungan logam berat timbal $(\mathrm{Pb})$ pada kerang Polymesoda erosa $L$ yang berada di perairan Tanjung Bunga Makassar dapat berasal dari keberadaan kapal nelayan yang lalu lalang serta banyaknya emisi gas buang yang senantiasa keluar melalui kendaraan-kendaraan yang melintasi area tersebut. Menurut Perkins (1979) dari 75\% kandungan timbal $(\mathrm{Pb})$ dalam bahan bakar bensin yang diemisikan ke udara oleh kendaraan bermotor sekitar $40 \%$ jatuh pada jarak dekat; $8 \%$ jatuh pada jarak agak jauh; 24\% jatuh pada jarak jauh; dan 3\% jatuh pada jarak yang tidak dapat diukur. Selain itu disebabkan pula oleh masuknya logam berat timbal $(\mathrm{Pb})$ ke perairan melalui pengkristalan timbal $(\mathrm{Pb})$ di udara dengan bantuan air hujan. Proses korosifikasi dari batuan mineral akibat hempasan gelombang dan angin yang juga merupakan salah satu jalur sumber timbal $(\mathrm{Pb})$ yang masuk kebadan perairan.

Efek toksik atau efek yang tidak diinginkan dalam sistem biologis, tidak akan dihasilkan oleh bahan kimia kecuali bahan kimia tersebut atau produk biotransformasinya mencapai tempat yang sesuai dalam tubuh pada konsentrasi dan lama waktu yang cukup untuk menghasilkan manifestasi toksik. Terjadi tidaknya respon toksik tergantung pada sifat kimia dan fisik dari bahan tersebut, situasi pemaparan, dan kerentanan sistem biologis dari subjek. Oleh Karena itu untuk dapat mengetahui karakteristik lengkap mengenai bahaya potensial dan toksisitas dari suatu bahan kimia tertentu perlu diketahui tidak hanya tipe efek yang dihasilkan dan dosis yang diperlukan untuk menghasilkan efek tersebut, tetapi juga 
informasi mengenai sifat bahan kimianya sendiri, pemaparannya, dan subjek. Jalur masuk ke dalam tubuh, jangka waktu dan frekuensi pemaparan merupakan salah satu faktor yang mempengaruhi toksisitas berkaitan dengan situasi pemaparan terhadap bahan kimia tertentu.

Meskipun dari hasil analisis pada kerang Polymesoda erosa $L$ yang diperoleh di perairan Tanjung Bunga Makassar menunjukkan hasil yang dekat dengan ambang batas baku mutu yang telah ditetapkan oleh Dirjen POM RI, namun bukan berarti bahwa kerang dari daerah tersebut aman untuk dikonsumsi, apalagi jika mengkonsumsinya dikatakan hampir setiap hari. Hal ini disebabkan karena logam berat timbal $(\mathrm{Pb})$ bersifat akumulatif dalam tubuh manusia sehingga keracunan akut dalam waktu dini belum dapat terdekteksi tetapi lama-kelamaan akan menghasilkan keracunan yang kronis yang pada akhirnya menyebabkan suatu penyakit yang menyerang saraf pusat apabila konsentrasi logam berat timbal $(\mathrm{Pb})$ tersebut di dalam tubuh manusia sudah tidak dapat ditolerir oleh tubuh manusia itu sendiri.

\section{KESIMPULAN}

Berdasarkan hasil penelitian dapat dikemukakan bahwa kandungan logam berat khususnya timbal $(\mathrm{Pb})$ pada Polymesoda erosa $L$ di perairan Tanjung Bunga Makassar tepat pada ambang batas baku mutu hasil perikanan (olahan lainnya) yakni sekitar 1,07 mg/kg sampai $2,05 \mathrm{mg} / \mathrm{kg}$ dan dinyatakan tidak layak untuk di konsumsi.

\section{REFERENSI}

Ahmad R., 2004. Kimia Lingkungan. Andi Yogyakarta. Universitas Negeri Jakarta. Jakarta.

Barnes DR., 1989. Invertebrata Zoology. $5^{\text {th }}$ Edition. CBS College Publishing Saunders College Publishing Holt, Rinerhart and Winston The Dryden Press. United State of America.

Dahuri. M, 2001. Pengelolaan Sumber Daya Pesisir dan Lautan Secara Terpadu. PT. Pradya Paramita. Jakarta.

Darmono, 1995. Logam dalam Sistem Biologi Mahkluk Hidup. UI-Press. Jakarta. 
Dharma B., 1988. Siput dan Kerang Indonesia Indonesian Shells II. PT. Sarana Graha. Jakarta.

Fardiaz S., 1992. Polusi Udara \& Air. Kanisius. Yogyakarta.

Hiatuddin. M, 2003. Melestarikan Sumber Daya Air Dengan Teknologi Rawa Buatan. Gajah Mada University Press. Yogyakarta.

Jasin M. Drs., 1991. Zoology Invertebrata. Sinar Wijaya. Surabaya.

Lu FC., 1994. Toksikologi Dasar. Universitas Indonesia Press. Jakarta.

Michael P., 1994. Metode Ekologi untuk Penyelidikan Ladang dan Laboratorium. UI Press. Jakarta.

Perkins, Henry C. 1979. Air Pollution. McGraw Hill. Kogakusha Ltd. Tokyo.

Soemirat. J, 2003. Toksikologi Lingkungan. Gajah Mada University Press. Yogyakarta.

Sorensen, E.M., 1991. Metal Poisoning In Fish. Ellish Horwood Limited, England.

Storer TI., 1957. General Zoology $3^{\text {th }}$ Edition. McGraw-Hill Book Company, Inc. Tokyo.

Suhardjo, 1990. Penilaian Keadaan Gizi Masyarakat. Departemen Pendidikan Kebudayaan Direktorat Jenderal Pendidikan Tinggi Pusat Antar Universitas Pangan dan Gizi. Institut Pertanian Bogor. Bogor.

Suwignyo. S, 2005. Avertebrata Air Jilid I. Penebar Swadaya. Bogor.

Talim S., 2004. Pemerintah Kota Makassar Laporan Kasus Lingkungan Hidup Tahun 2004. Bapedalda Kota Makassar. Makassar.

Wahab. W. Abd, 2006. Kajian Desain Elektroda Selectif Ion Untuk Logam Berat: Zn, Cd, dan Pb Terhadap Analisis Pencemaran Sedimen Laut Kawasan Pesisir Pantai Makassar. Jurusan Kimia FMIPA UNHAS. Makassar. 